\title{
Evaluation of Biogas Potential of Students Hostel Kitchen Food Wastes
}

\author{
A. Krishnaveni*, C. Sivakumar, D. Shanmugapriya,S. Shobana,' \\ M. Siva and M. Pandiayan* \\ Agricultural College and Research Institute, Tamil Nadu Agricultural University, \\ Vazhavachanur-606 753, Thiruvannamalai District, Tamil Nadu, India \\ *Corresponding author
}

A B S T R A C T

\section{Keywords \\ Anaerobic bottles, Biodegradable hostel kitchen food waste, Bio gas, Total solids \\ Article Info \\ Accepted: \\ 20 December 2019 \\ Available Online: \\ 10 January 2020}

The production of biogas from the food wastes is important to recycle it an effective way to avoid mixing of odorous gas in to the atmosphere. The biogas production potential of food waste is higher due to high organic nutrients and starch contents. This researchpaper indicate that the potential of food waste for biogas production. The combinations of kitchen food waste with different ratios of cow dung were involved for the production of biogas production. The result indicated that the treatment containing $100 \%$ kitchen food waste alone produced maximum quantity of biogas $2877.5 \mathrm{ml}$ for about 60 days when compared to other treatments.

\section{Introduction}

The depletion of conventional resources like coal, petroleum, natural gases etc., are in rapid way due to over population and modern life style in urban areas in addition to its prize fluctuation in international market, which positioned us for the exploration of alternated energy sources in an economical way. The wastes are available in different sectors like house hold, hostels, and industries for the production of energy especially for in urban and rural areas. In the World, the alarming problem is pollution because of the different degradable and non degradable wastes from many sources. These wastes are generally managed through land filling orburing in land surface which affect the quality of atmospheric air and groundwater. The general concepts of Recycle, Reduce and Reuse have been generally employed for waste to wealth based on the chemical composition of waste. Peter Wieland (2010) reviewed that biochemical parameter in the feedstock influences the yield of biogas through activity of microbial conversion.

The greenhouse gases emission particularly carbon dioxide is an major issue for global warming, so effective management of waste is 
essential. In most of cities and rural areas, kitchen food waste is discarded without any treatment for decomposition or otherwise disposed as landfill, which ultimately leads to atmospheric pollution and also public health problems like asthma, diarrhoea, cholera, malaria, typhoid etc., due to inadequate management. The waste dumping sites are breeding place for disease causing microorganisms, flies, rats, mosquitoes and rats. The unbearable odorous gss emitted from the dumping sites leads to global warming.

Based on the need of the fuel cost, there is a demand for the production of energy from different waste for the future use. In our project, we focused on utilizing kitchen wastes for the production of useful biogas. So biogas can be used as an alternate fuel in the engines which cause no harmful emissions as that of other fossil fuels. There are many sources available for gas production, but highly degradable and odorous gas producing kitchen food wastes was taken for this study because the reaction time is faster and easily available. Kitchen waste is organic material having the high calorific value and nutritive value for the microbial reactions. The food wastes have the efficiency of biogas production, which was reported by different scientific workers in different organic wastes for the production of biogas. In India, approximate amount of 1.0 lakh metric tons of different solid wastes and also the per capita waste generation rate has increased from $0.44 \mathrm{~kg}$ per day in 2001 to 0.6 kg per day in 2011.

The biogas was different from other renewable energies through utilizing waste as input and also it can be converted into fertilizer in agricultural crop management. Biogas does not require any advanced technological system for its producing from the waste materials and also has no geographical limitations. The biofuels are having greater economic advantage of utilizing for transport rather than power production when compared with other fuel sources with regards to its effect on the environment, finical dependence, and functioning of the plant in Ireland. The optimum amount of feed stock with total solids is essential for biogas production. HilkiahIgoni (2008) reported that the concentration of Total Solids in the Solid Wastes has influenced the $\mathrm{pH}$, temperature and activity of microorganisms during the decomposition process for the production of biogas in an anaerobic continuously stirred tank reactor. The Appropriate Rural Technology Of India (ARTI), developed by Anand Karve (2003) in Pune resulted that the starch and sugar containing food materials viz., spoiled grain flour rotten and over ripened fruits and vegetables, unutilized green leaves and rhizomes, house hold kitchen waste and food wastes etc. were utilized for the production of biogas in the compact system. In this system, two $\mathrm{kg}$ of food waste has produced $500 \mathrm{~g}$ within $24 \mathrm{hrs}$, whereas the conventional system of cow dung requires 40 $\mathrm{kg}$ for the same amount of gas with 40 days duration. Ravi et al., (2013) compared different ratios of kitchen waste in different materials fabricated biogas plant and then concluded that black painted aluminum materials biogas plant was best for community level biogas production from kitchen waste. Cunsheng Zhang et al., (2014) invented that the co-digestion of food waste with waste water enhanced the biodegradation of long chain fatty acids and resulted higher methane yield.

\section{Microbial action during the anaerobic biogas production}

During the biogas production the methanogens and acid-producing bacteria will act in the food materials in a symbiotic way through acid producing bacteria create an anaerobic conditions for methane producing to produce methane. In turn the methane producing 
microorganisms consume the intermediate compounds of the acid producing bacteria because intermediates create toxic to the acidproducing microorganisms Lissens et al., (2004) stated that the total biogas yield was increased from available biogas 50\% to $90 \%$ in the continuously stirred tank reactor containing the waste material and then inoculated with bacteria Fibrobacter succinogens to produce the biogas. Kumar $e t$ al., (2004) observed the methane emission from solid waste landfills. The review of Cunsheng Zhang et al., (2014) stated that the anaerobic digestion of food waste can produce biogas. Abishek et al., (2015) stated that the biogas from kitchen Waste can carried in anaerobic digester. The production of biogas from fruit and vegetable wastes mixed with different wastes was experimented by Leta Deressa (2015). The biogas quantity was increased with inoculating the microorganism and the anaerobic microorganisms for converting the kitchen food waste to biogas was done by Malakahmad et al., (2009). The biogas was produced from different food wastes by Sudha. andSatyanarayana (2012). Potivichayanon et al., (2011) stated that the biogas can be obtained from bakery waste by Pseudomonas aeruginosa

\section{Materials and Methods}

The study was conducted in Agricultural College and Research Institute, TNAU, Vazhavachanur, Thiruvannamalai, Tamil Nadu during 2019. In this college, there are two hostelsfor both boys(Thenpennai) and girls (Gomuki). In this mess, there are around 300 students are dinning in breakfast, lunch and dinners constitutes vegetarian and non vegetarian items. The discarded vegetable and fruit skin, wasted food materials and other materials were utilized in this study. The treatment follows.

\section{Treatment details}

$\begin{array}{ll}\mathrm{T}_{1} & \text { Cowdung alone } 100 \% \\ \mathrm{~T}_{2} & \text { Kitchen waste alone } 100 \% \\ \mathrm{~T}_{3} & \text { Kitchen waste } 50 \%+\text { Cowdung } 50 \% \\ \mathrm{~T}_{4} & \text { Kitchen waste } 75 \% \text { + Cowdung } 25 \% \\ \mathrm{~T}_{5} & \text { Kitchen waste } 25 \%+\text { Cowdung } 75 \%\end{array}$

\section{Treatment Details}

$\mathrm{T}_{1} \quad$ Cowdung alone $100 \%$

$\mathrm{T}_{2} \quad$ Kitchen waste alone $100 \%$

$\mathrm{T}_{3} \quad$ Kitchen waste 50\% + Cowdung 50\%

$\mathrm{T}_{4} \quad$ Kitchen waste $75 \%$ + Cowdung $25 \%$

$\mathrm{T}_{5} \quad$ Kitchen waste $25 \%$ + Cowdung $75 \%$

\section{Mixing ratio of different treatments}

$500 \mathrm{~g}$ cow dung $+250 \mathrm{ml}$ water

$500 \mathrm{~g}$ kitchen waste $+250 \mathrm{ml}$ of water

$250 \mathrm{~g}$ of cow dung +250 gram kitchen wastes+ $250 \mathrm{ml}$ of water

$375 \mathrm{~g}$ of kitchen waste $+125 \mathrm{~g}$ of cowdung + $250 \mathrm{ml}$ of water

$375 \mathrm{~g}$ of cow dung $+125 \mathrm{~g}$ of kitchen waste + $125 \mathrm{ml}$ of water 
The kitchen wastes were collected from the breakfast, dinner and lunch for about 7 days. The collected food wastes were segregated and then dried in Hot airoven @ $120{ }^{\circ} \mathrm{C}$ to get optimum moisture content. The food waste sample was estimated for its $\mathrm{pH}$, EC, Total Solids. The collected waste were mashed through wooden mortar and then filled in different bottles and then closed with rubber cork to create an anaerobic condition.

\section{Estimation of chemical parameters of food wastes}

pH

The food waste samples was mixed with distilled water in the ration of 2.5:1 and then fed in the $\mathrm{pH}$ meter and then recorded the meter reading

\section{EC}

The food waste samples was mixed with distilled water in the ration of 2.5:1 and then fed in the Conductivity Bridge and then recorded the meter reading

\section{Total Solids (TS)}

The total solid in the food waste was estimated by 10 gram food waste was taken in the container and heated at $105{ }^{\circ} \mathrm{C}$ and calculated based on the formula and expressed in percentage.

$$
\text { TS \% }=(\mathrm{W} 1-\mathrm{W} 2 / \mathrm{W} 3-\mathrm{W} 2) \times 100
$$

W1 -weight of the dried crucible + dried residue

W2-Weight of the crucible (gm)

W3- Initial weight of the wet sample (substrate) + crucible

\section{Estimation of biogas}

The biogas was estimated through water displacement method at different stages of anaerobic process. The initial reading was taken through placing the gas tube of anaerobic bottle in to known volume of water containing measuring cylinder. The displacement of water by biogas was observed and then noted the value.

\section{Results and Discussion}

The kitchen waste were continuously collected at different session's viz., Breakfast, Lunch and Dinner and presented in Table -1 . The biodegradable wastes were collected and weighed (Table -2). An amount of $162.5 \mathrm{~kg}$ of bio- degradable wastes are collected in the students hostel mess for one week. so, it was an excellent source for producing bio gas.

The composition of kitchen waste of then pennai and gomuti hostels was segregated and expressed in Fig -1

From results it has been seen that $\mathrm{pH}$ reduces as the process going on as the bacteria produces fatty acids. Here methanogens bacteria which utilize the fatty acids, is slow reaction compare to other so it is rate limiting step in reaction. In T2 which contains kitchen waste $(100 \%) \mathrm{pH}$ decreases highly means

\section{Estimation of biogas}

From the result it has been observed that in $\mathrm{T}_{2}$ which contain $100 \%$ kitchen waste alone produced more biogas @ $2877.5 \mathrm{ml}$ when compare to other treatments. In $\mathrm{T}_{2}$ with kitchen waste produces average 47 per cent more gas than $\mathrm{T}_{1}(100 \%$ cow dung) of 931.5 and 76 per cent more gas than $\mathrm{T}_{3} 683.5$ and 77 per cent more gas than $\mathrm{T}_{4}$ with $885 \mathrm{ml}$ and 81 per cent more gas than T5 $(557.5 \mathrm{ml})$. 
Table.1 Quantity of food wastes collected at different sessions in a week

\begin{tabular}{|c|c|c|c|c|c|c|c|}
\hline \multirow[t]{2}{*}{ Date } & \multirow[t]{2}{*}{ Day } & \multicolumn{3}{|c|}{ Komuki girls hostel (kg) } & \multicolumn{3}{|c|}{ Thenpennai boys hostel (kg) } \\
\hline & & Breakfast & Lunch & Dinner & Breakfast & Lunch & $\begin{array}{c}\text { Dinne } \\
\mathbf{r}\end{array}$ \\
\hline 23.1.19 & Sunday & 5 & 4 & 3 & 3.5 & 3 & 3 \\
\hline 24.1.19 & Monday & 4 & 6 & 4.5 & 5 & 3.3 & 2 \\
\hline 25.1.19 & Tuesday & 3.5 & 5 & 4.5 & 4 & 5 & 3 \\
\hline 26.1.19 & Wednesday & 4 & 6 & 2 & 2.5 & 2 & 3.5 \\
\hline 27.1.19 & Thursday & 5 & 2 & 2.5 & 4 & 2 & 3.9 \\
\hline 28.1.19 & Friday & 3 & 7 & 4 & 5 & 2 & 2.3 \\
\hline 29.1.19 & Saturday & 4 & 6 & 4.5 & 4 & 6 & 5 \\
\hline \multicolumn{2}{|c|}{ Total } & \multicolumn{3}{|c|}{$=89.5 \mathrm{~kg}$} & \multicolumn{3}{|c|}{$=73 \mathrm{Kg}$} \\
\hline
\end{tabular}

Table.2 Quantity of biodegradable food wastes in different sessions in a week

\begin{tabular}{|c|l|c|c|}
\hline \multirow{2}{*}{ Date } & \multicolumn{1}{|c|}{ Day } & $\begin{array}{c}\text { Weight }(\mathbf{k g}) \\
\text { Gomuki girls hostel }\end{array}$ & $\begin{array}{c}\text { Weight (kg) } \\
\text { Thenpennai boys hostel }\end{array}$ \\
\cline { 3 - 4 } & & Bio - degradable & Bio -degradable \\
\hline $\mathbf{2 3 . 1 . 1 9}$ & Sunday & 12 & $\mathbf{9 . 5}$ \\
\hline $\mathbf{2 4 . 1 . 1 9}$ & Monday & 14.5 & $\mathbf{1 0 . 3}$ \\
\hline $\mathbf{2 5 . 1 . 1 9}$ & Tuesday & 13 & $\mathbf{1 2}$ \\
\hline $\mathbf{2 6 . 1 . 1 9}$ & Wednesday & 12 & $\mathbf{8}$ \\
\hline $\mathbf{2 7 . 1 . 1 9}$ & Thursday & 9.5 & $\mathbf{8 . 9}$ \\
\hline $\mathbf{2 8 . 1 . 1 9}$ & Friday & 14 & $\mathbf{9 . 3}$ \\
\hline $\mathbf{2 9 . 1 . 1 9}$ & Saturday & $\mathbf{1 4 . 5}$ & $\mathbf{1 5}$ \\
\hline
\end{tabular}

Table.3 Quantity of biogas in different inputs in the treatments

\begin{tabular}{|l|c|c|c|c|c|}
\hline \multirow{2}{*}{ Treatment days } & \multicolumn{5}{|c|}{ Quantity of biogas ( ml) } \\
\cline { 2 - 6 } & $\mathbf{T}_{\mathbf{1}}$ & $\mathbf{T}_{\mathbf{2}}$ & $\mathbf{T}_{\mathbf{3}}$ & $\mathbf{T}_{\mathbf{4}}$ & $\mathbf{T}_{\mathbf{5}}$ \\
\hline Day -1 & 4 & 16 & 3 & 7 & 5 \\
\hline Day -2 & 5 & 22 & 3.5 & 7.5 & 6 \\
\hline Day -3 & 6.5 & 25 & 4 & 8 & 8.5 \\
\hline Day -4 & 6.5 & 27.5 & 4.5 & 8.5 & 9 \\
\hline Day -5 & 9 & 38 & 6 & 11 & 9.5 \\
\hline Day -6 & 10.5 & 38.5 & 8 & 12 & 11 \\
\hline Day -7 & 13 & 39 & 8.5 & 13 & 12 \\
\hline Day -8 & 15 & 40 & 14 & 14.5 & 13 \\
\hline Day -9 & 18 & 42.5 & 16 & 15 & 15 \\
\hline Day -10 & 20 & 43 & 16 & 16 & 15.5 \\
\hline Day -11 & 22 & 43 & 18 & 16 & 17 \\
\hline Day -12 & 25 & 44 & 18.5 & 17 & 17 \\
\hline Day -13 & 28 & 46 & 21 & 17.5 & 17 \\
\hline Day -14 & 30 & 46.5 & 24 & 18 & 18 \\
\hline
\end{tabular}




\begin{tabular}{|c|c|c|c|c|c|}
\hline Day -15 & 33 & 48 & 24 & 18 & 18.5 \\
\hline Day -16 & 34.5 & 49 & 24.5 & 18 & 19 \\
\hline Day -17 & 35 & 49 & 25 & 19 & 19 \\
\hline Day -18 & 35 & 50 & 25 & 19.5 & 19.5 \\
\hline Day -19 & 36 & 51.5 & 27 & 20 & 20 \\
\hline Day -20 & 39 & 52 & 27.5 & 22 & 23.5 \\
\hline Day -21 & 40 & 55.5 & 29 & 22 & 26 \\
\hline Day -22 & 42 & 58 & 35 & 23 & 28 \\
\hline Day -23 & 41 & 60 & 35 & 24 & 29 \\
\hline Day -24 & 39 & 61 & 36 & 27 & 29 \\
\hline Day -25 & 35 & 63.5 & 39.5 & 29 & 30 \\
\hline Day -26 & 33 & 64 & 33 & 29 & 27 \\
\hline Day -27 & 33 & 64.5 & 30 & 30 & 22 \\
\hline Day -28 & 31.5 & 65 & 28 & 32.5 & 20 \\
\hline Day -29 & 29.5 & 66 & 24 & 33 & 19 \\
\hline Day -30 & 29 & 66.5 & 20 & 35 & 19 \\
\hline Day -31 & 29 & 68 & 16 & 33 & 17 \\
\hline Day -32 & 24 & 69 & 13 & 31 & 14 \\
\hline Day -33 & 21 & 67.5 & 11 & 30 & 11 \\
\hline Day -34 & 19 & 66 & 7 & 27 & 9 \\
\hline Day -35 & 15 & 66 & 3.5 & 25 & 3 \\
\hline Day -36 & 14 & 65 & 2.5 & 23 & 3 \\
\hline Day -37 & 13.5 & 64.5 & - & 20 & - \\
\hline Day -38 & 11 & 64 & - & 20 & - \\
\hline Day -39 & 9 & 63 & - & 19 & - \\
\hline Day -40 & 3 & 63 & - & 18 & - \\
\hline Day -41 & - & 62 & - & 14 & - \\
\hline Day -42 & - & 60 & - & 12 & - \\
\hline Day -43 & - & 58 & - & 9 & - \\
\hline Day -44 & - & 57 & - & 8 & - \\
\hline Day -45 & - & 53 & - & 4 & - \\
\hline Day -46 & - & 51 & - & 3 & - \\
\hline Day -47 & - & 50 & - & 2 & - \\
\hline Day -48 & - & 49 & - & 2 & - \\
\hline Day -49 & - & 48.5 & - & 2 & - \\
\hline Day -50 & - & 48 & - & 1 & - \\
\hline Day -51 & - & 42.5 & - & - & - \\
\hline Day -52 & - & 42 & - & - & - \\
\hline Day -53 & - & 35 & - & - & - \\
\hline Day -54 & - & 31 & - & - & - \\
\hline Day -55 & - & 28.5 & - & - & - \\
\hline Day -56 & - & 23 & - & - & - \\
\hline Day -57 & - & 17 & - & - & - \\
\hline Day -58 & - & 15 & - & - & - \\
\hline Day $\mathbf{- 5 9}$ & - & 7 & - & - & - \\
\hline Day -60 & - & 4 & - & - & - \\
\hline Total & 931.5 & 2877.5 & 683.5 & 885 & 557.5 \\
\hline
\end{tabular}


Table.4 Changes of parameters in $\mathrm{T}_{2}$ treatment during anaerobic process

\begin{tabular}{|l|l|l|}
\hline Parameters & Initial day & After a week \\
\hline pH & 7.3 & 6.1 \\
\hline EC $(\mathbf{d s} / \mathbf{m})$ & 1.5 & 1.10 \\
\hline Total Solids (\%) & 11.9 & 10.3 \\
\hline
\end{tabular}

Plate.1 Different Methodology involved in production of biogas

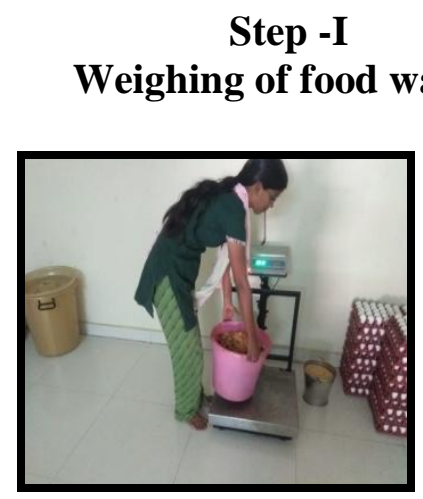

Step - IV

Estimation of $\mathrm{pH}$ and $\mathrm{EC}$

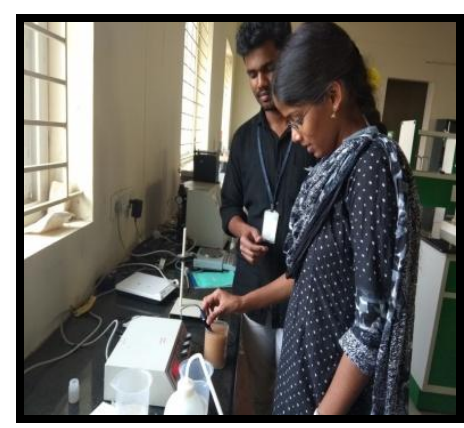

Step - II

Grinding of food wastes

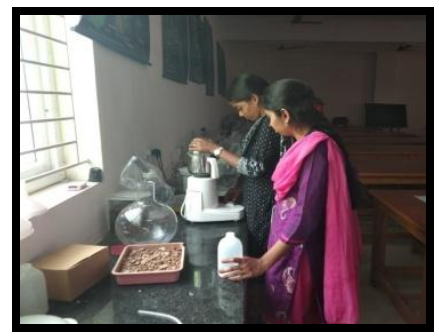

Step -V

Estimation of TS

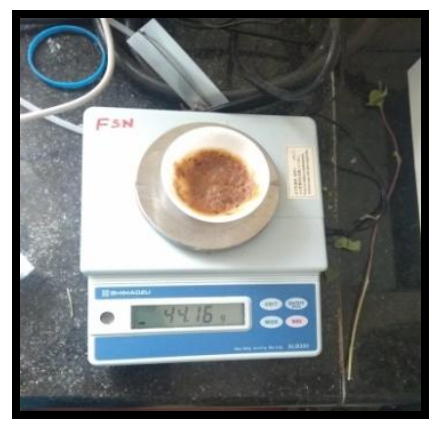

Step - III

Drying the food wastes in

Hot air

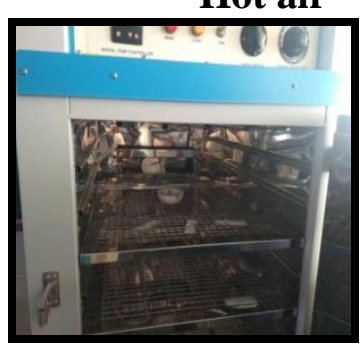

Step -VI

Filling of food waste in the bottles

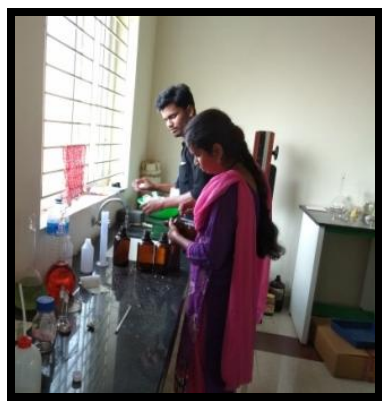

Experimental Set up for Food Solid waste for biogas production 

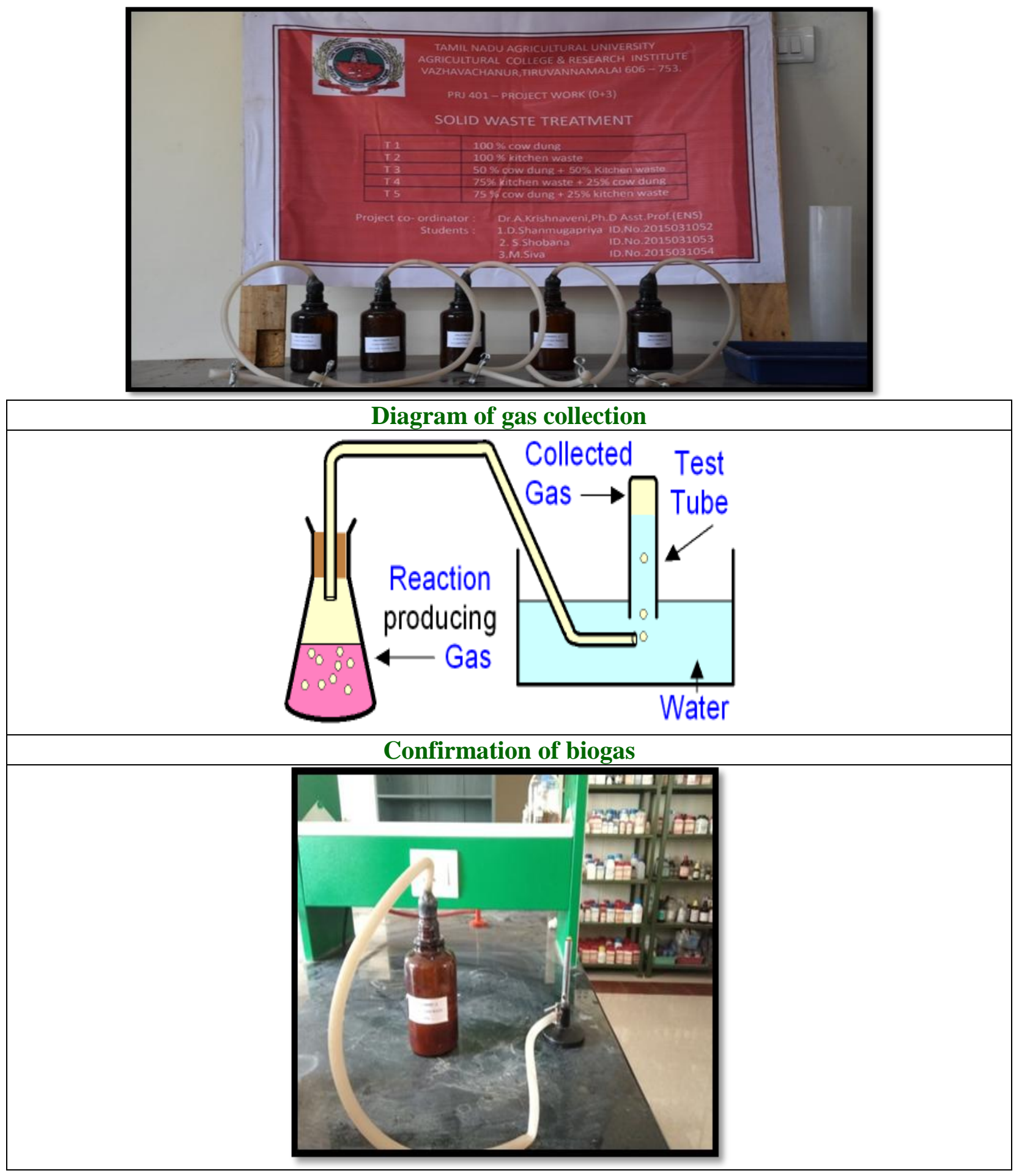

Fig.1 Composition in the food wastes collected in the hostel mess at different sessions in a week 


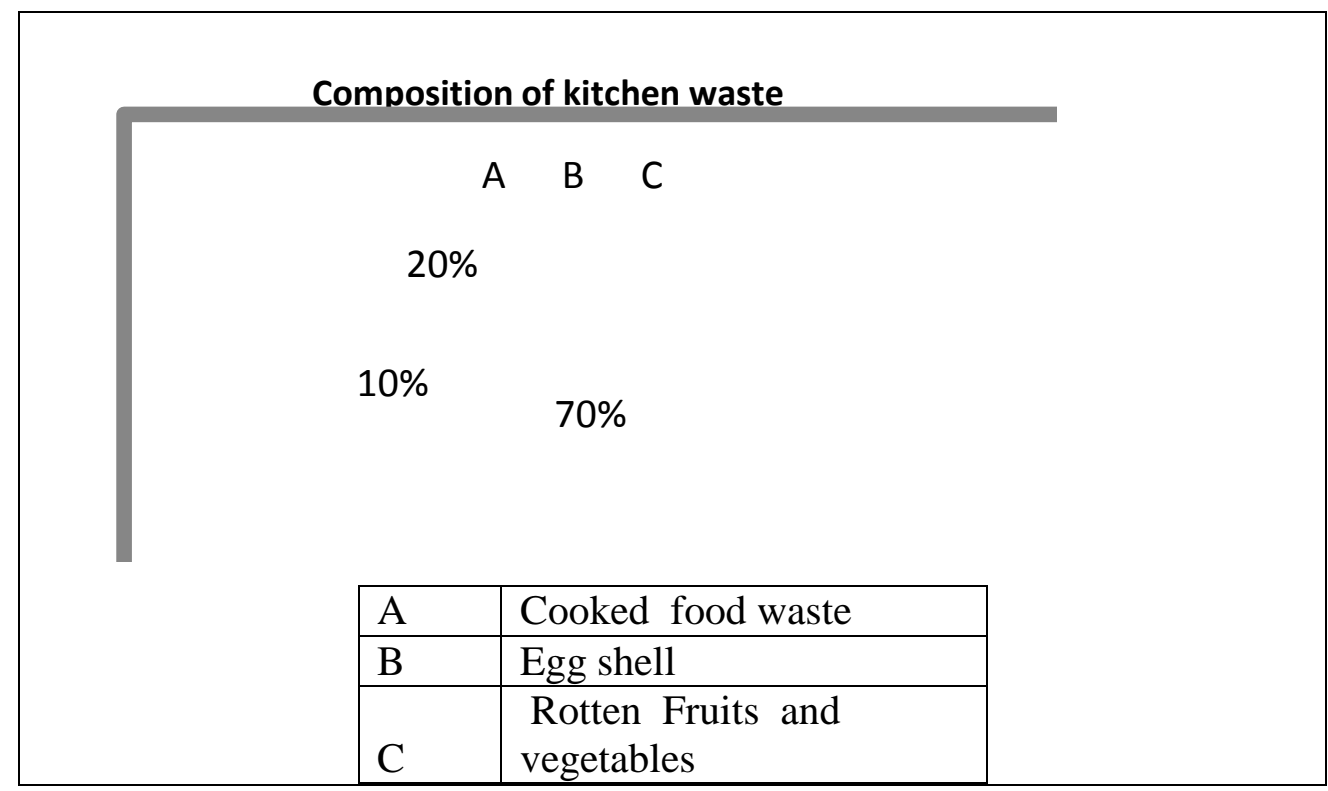

\begin{tabular}{|l|l|l|}
\hline \multicolumn{1}{|c|}{$\begin{array}{c}\text { Composition of food } \\
\text { waste }\end{array}$} & \multicolumn{1}{|c|}{$\begin{array}{c}\text { Egg shell } \\
\text { A }\end{array}$} & \multicolumn{1}{c|}{$\begin{array}{c}\text { Composition of Rotten } \\
\text { fruits \& vegetables } \\
\text { C }\end{array}$} \\
\hline Pongal & Broken eggs & Rotten tomatoes \\
\hline Poori & Boiled Egg Shell & Onion peel \\
\hline Idli & Omlet Egg shell & Banana Peel \\
\hline Dosa & & Potato peel \\
\hline Vada & & Rotten chilly \\
\hline Rice with sambar & & Cabbage leaf waste \\
\hline Chicken gravy waste & & Rotten cucumber \\
\hline
\end{tabular}

Fig.2 Total quantity of biogas in different treatments

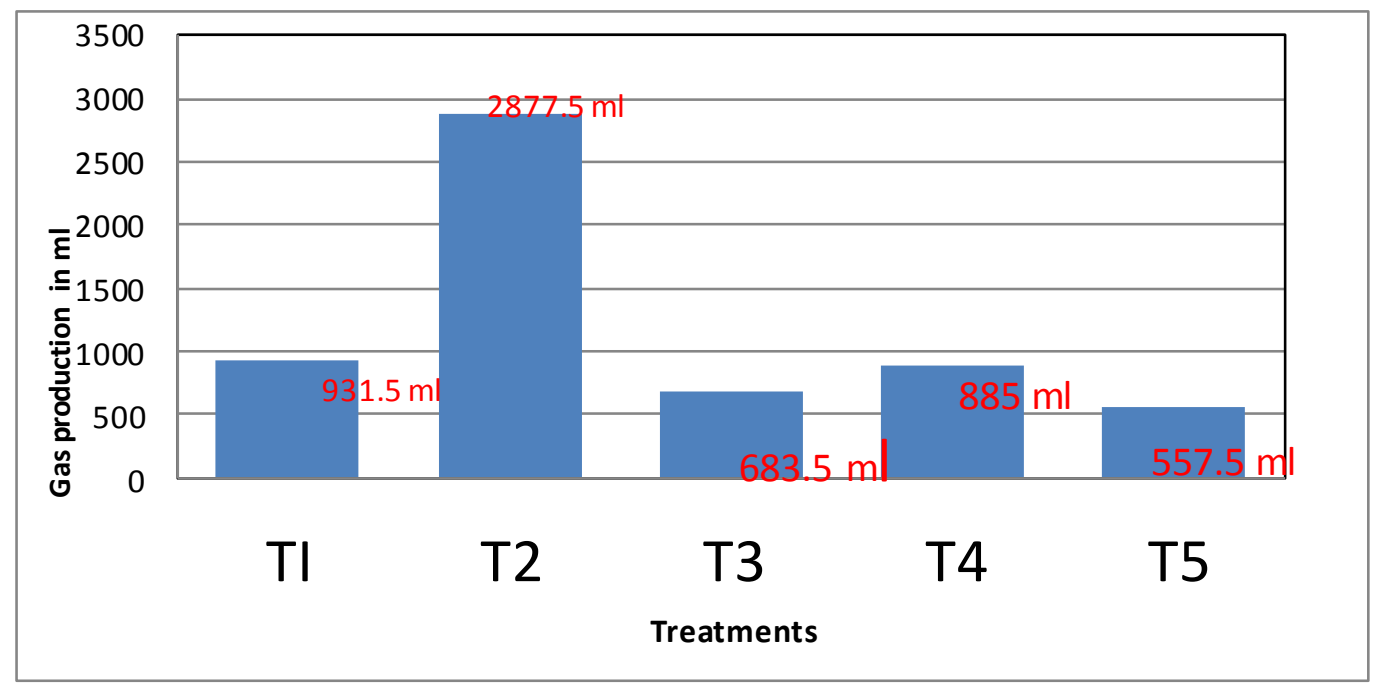


Fig.3 $\mathrm{pH}$ and EC variation in the treatments in different days

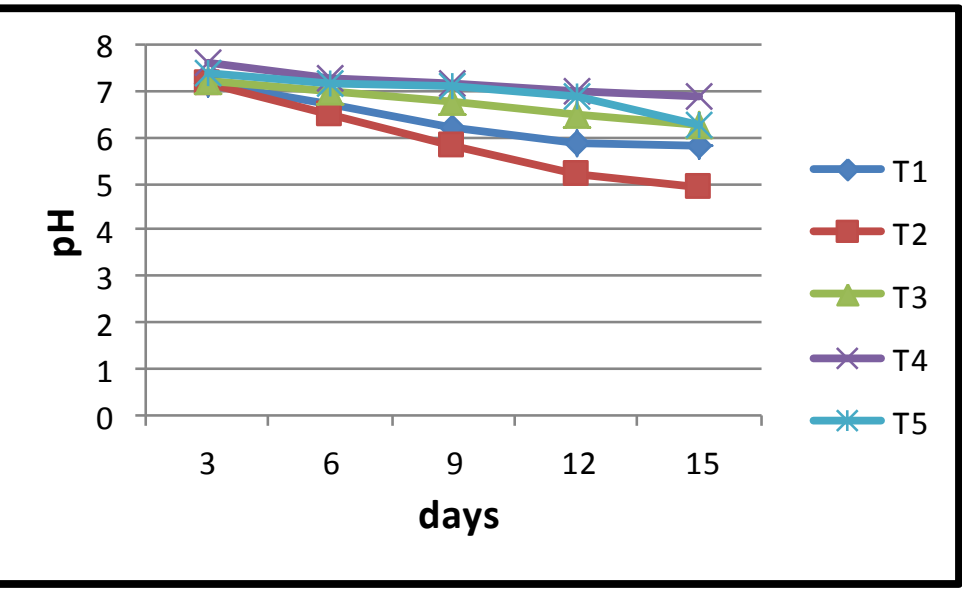

The kitchen waste produces more gas than cow dung because the kitchen waste contains more nutrients along with carbohydrate than cow dung. The kitchen waste released more biogas compared to other inputs (Table -3).

The finding was similar to that of Srinvasa Reddy et al., (2017) stating that the bio gas was produced from kitchen and food wastes of residential community in Mumbai city suburbs through a fabricated anaerobic digester.

The total quantity of biogas in different treatments were expressed in Fig -2 and initial days up to 15 days for the production of biogas in different treatments were presented in Fig -3.

\section{pH, EC and Total solids}

The $\mathrm{pH}$ and EC starts decreasing as acid concentration increases in the bottles and $\mathrm{pH}$ decreases below 7 after 4-5 days. The addition of water diluted and then increased the $\mathrm{pH}$. The gas production again starts increasing. Therefore, we can infer that acid concentration greatly affects the biogas production. The EC and total solids were start decreasing in the anaerobic process (Table 4).

In conclusion, the gap between demand and supply for energy sources can be minimised by converting bio degradable hostel kitchen waste into a biogas in an economical way.Among the different treatments, Treatment $\mathrm{T}_{2}(100 \%$ kitchen waste ) alone produced more amount of biogas. The biogas can be used for cooking food items instead of LPG and also used to operate generators instead of electricity. It is a source of renewable green energy. The left over sludge can be packed and used as a manure and compost for agriculture farming.

\section{References}

Abishek Joel J., Murali G., Ravishankar, Sibichakravarthy M., Sundhirasekar, 2015. Performance Analysis of Anaerobic Digestion to extract Biogas from Kitchen Waste International Journal of Scientific \& Engineering Research. 6(3): 2229-5518

Cunsheng Zhang, Haiia Su, Jan Baeyens, and Tianwei Tan, 2014.Reviewing the Anaerobic Digestion of Food Waste for Biogas Production. Science Direct, Renewable and Sustainable Energy Reviews. 38: 383-392

HilkiahIgoni, A M. F. N. Abowei, M. J. Ayotamuno and C. L. Eze.2007.Designs of anaerobic digesters for producing biogas from municipal solid-waste. 
Applied Energy 85(6):430-438

Karve .A.D, 2003 .Compact Biogas Plant, A Low Cost Digester for Biogas from Waste Starch. http://www.arti-india.org.

Kumar, S., Gaikwad, S.A., Shekdar, A.K., Kshirsagar, P.K., Singh, R.N. 2004. Estimation method for national methane emission from solid waste landfills. Atmospheric Environment. 38: 34813487.

LetaDeressa, 2015. Production of Biogas from Fruit and Vegetable Wastes Mixed with different Wastes Environment and Ecology Research 3(3):.65-71

Lissens, G., Thomsen, A.B., Baere, L., Verstraete, W., and Ahring B.2004.Thermal wet oxidation improves anaerobic biodegradability of raw and digested bio waste. Environmental Science and Technolog. 38(2): 3418 - 3424

Malakahmad, A, S M Zain, N E Ahmad Basri, S R Mohamed Kutty and M H Isa, 2009. Identification of Anaerobic Microorganisms for Converting Kitchen Waste to Biogas. World Academy of Science, Engineering and Technology,
3. $12-20$

Peter Wieland, 2010.Biogas Production: Current State and Perspectives. Appl Microbial Biotechnol, 85(1):849 - 860

Potivichayanon, S., T Sungmon, W Chaikongmao, and S Kamvanin, 2011. Enhancement of Biogas Production from Bakery Waste by Pseudomonas aeruginosa" World Academy of Science, Engineering and Technology, 5(1): 08- 29

Ravi P Agrahari and G N Tiwari, 2013. Production of biogas using kitchen waste. Int. Journal of Energy Science. 3(1): $12-06$

Srinvasa Reddy, N., Satyanarayana, S.V., Sudha, G. 2017. Bio Gas Generation from Biodegradable Kitchen Wastes. International Journal of Environment, Agriculture and Biotechnology. 2 (2): $680-694$

Sudha, G. Satyanarayana, S.V. 2012. Production of Biogas from Different Food wastes. International Journal of Applied Environmental Sciences, 7(1): $1-7$.

\section{How to cite this article:}

Krishnaveni, A., C. Sivakumar, D. Shanmugapriya,.S. Shobana,,M. Siva and Pandiayan, M. 2020. Evaluation of Biogas Potential of Students Hostel Kitchen Food Wastes. Int.J.Curr.Microbiol.App.Sci. 9(01): 457-467. doi: https://doi.org/10.20546/ijcmas.2020.901.050 